TEODORO JS; MARTINS JFS; ROSAAPSA; CASTRO CM; CUNHA US. 2014. Characterization of potato genotypes for resistance to Diabrotica speciosa. Horticultura Brasileira 32: 440-445. DOI - http://dx.doi.org/10.1590/S0102-053620140000400011

\title{
Characterization of potato genotypes for resistance to Diabrotica speciosa
}

\author{
Jefferson S Teodoro'; José FS Martins ${ }^{2}$; Ana PSA Rosa ${ }^{2}$; Caroline M Castro ${ }^{2}$; Uemerson S Cunha ${ }^{1}$ \\ ${ }^{1}$ UFPel-FAEM, Depto. Fitossanidade, C. Postal 354, 96010-900 Pelotas-RS; jsilveirat1984@gmail.com; uscunha@yahoo.com.br; \\ ${ }^{2}$ Embrapa Clima Temperado C. Postal 403, 96001-970 Pelotas-RS; jose.martins@embrapa.br; ana.afonso@embrapa.br; caroline.castro@ \\ embrapa.br
}

\begin{abstract}
The potato crop is attacked by many pests, among which the Diabrotica speciosa (Coleoptera: Chrysomelidae) is considered the main one. Considering chemical control failures associated with the requirements of integrated potato production (IPP) requiring sustainable measures, this study aimed to characterize advanced clones breeding program of Embrapa for resistance to insect infestation in artificial conditions. Tests were carried out in a greenhouse without choice of plants and tubers of four clones of Embrapa (C2337-06-02, C2337-18-02, C2342-1-02, C2362-02-02), a standard-resistant clone (NYL 235-4) and a susceptible standard cultivar (Asterix). Results of susceptibility of 'Asterix' and resistance of 'NYL 235-4' and 'C2342-1-02', both in shoots and in tubers, predominated. Thus indicating a typical behavior of tolerance of 'NYL 235-4' and 'C2337-06-02' to insect attack, both in the shoots and in the tubers. Clones C2337-06-02 and C2362-02-02 expressed resistance to the attack of the young stage of the insect in the tubers. Three potato genotypes derived from the wild species Solanum berthaultii (NYL 235-4, C2337-06-02, C2362-02-02) even under infestation of D. speciosa, showed agronomic traits determinant of greater commercial acceptance of tubers such as steady productivity, elongated shape, skin smoothness and shallower depth of the eye (vegetative bud).
\end{abstract}

Keywords: Solanum tuberosum, corn rootworm, leaves, tubers, plant resistance.

\begin{abstract}
RESUMO
Resistência de genótipos de batata a Diabrotica speciosa

A cultura da batata é hospedeira de diversos insetos, sendo a vaquinha, Diabrotica speciosa (Coleoptera: Chrysomelidae), um dos mais nocivos. Devido às falhas de controle químico, associadas às exigências da produção integrada da batata (PIB) exigindo medidas sustentáveis, objetivou-se caracterizar clones avançados do programa de melhoramento genético de batata da Embrapa quanto à resistência ao inseto, em condições de infestação artificial. Realizaram-se ensaios sem chance de escolha em casa-de-vegetação, utilizando-se plantas e tubérculos de quatro clones da Embrapa (C2337-06-02, C2337-1802, C2342-1-02 e C2362-02-02), um clone padrão-resistente (NYL 235-4) e uma cultivar padrão-suscetível (Asterix). Predominaram resultados de suscetibilidade da 'Asterix' e de resistência do 'NYL 235-4' e 'C2342-1-02', tanto na parte aérea como em tubérculos. Evidenciou-se comportamento típico de tolerância de 'NYL 235-4' e 'C2337-06-02' ao ataque do inseto, tanto na parte aérea das plantas como nos tubérculos. Os clones C2337-06-02 e C2362-02-02 manifestaram resistência ao ataque de larvas nos tubérculos. Três clones de batata derivados da espécie silvestre Solanum berthaultii (NYL 235-4, C2337-06-02, C2362-02-02), mesmo sob infestação de $D$. speciosa, apresentaram caracteres agronômicos determinantes de maior aceitação comercial de tubérculos tais como manutenção de produtividade, formato alongado, película lisa e menor profundidade do olho (gema vegetativa).
\end{abstract}

Palavras-chave: Solanum tuberosum, vaquinha, folhas, tubérculos, resistência de plantas.

(Recebido para publicação em 4 de julho de 2013; aceito em 14 de agosto de 2013) (Received on July 4, 2013; accepted on August 14, 2014)

$\mathrm{T}$ The potato (Solanum tuberosum) is one of the most important crops in the world, surpassed in production, in terms of human consumption, only by rice and wheat (CIP, 2010). Due to high demands on the quality of tubers, it is essential to know the main phytosanitary problems in crop in the growing environment, besides the influence of management, fertilization and the cultivars chosen (Nunes, 2002; Quadros et al., 2009), as these will set the quality of the final product.
Among the various species of insects that attack the potato crop, Diabrotica speciosa is considered one of the major (Souza et al., 2006). In adult form (beetle), feeding on leaflets causes the roughness of the leaf and therefore reduces production of tubers (Lara et al., 2004). In the larval stage, known as rootworm, acting as soil pest, the insect damages stolons and forms galleries in tubers (Furiatti, 2009). Control is done systematically with chemical insecticides, applied in a generalized way in planting furrows or via foliar sprays (Souza et al., 2008).

The integrated potato production system, besides being economic, aims to meet the final product, prioritizing the use of proper management and rational use of agrochemicals, in order to minimize environmental impact and to improve the quality of human health. Thus, the overall goal of the system is to raise the quality standards and competitiveness of the potato, through the sustainable management of 
agricultural production (Boulomytis \& Júnior, 2013).

Due to some disadvantages of using chemical insecticides on potatoes, other control methods against $D$. speciosa have been studied, including the host plant resistance (Furiatti, 2009). This method, among other advantages, can keep the insect population in lower levels in relation to the economic thresholds, reducing the expenses on control and environmental impact (Lara et al., 2004). In order to obtain cultivars resistant to arthropod pests like D. speciosa, studies need to be done to clarify the causes of different types of resistance (antibiosis, antixenosis and/or tolerance), which in Solanum spp. can be associated with morphological and/or chemical mechanisms of plants such as trichomes and hydrocarbon respectively (Fernandes et al., 2012).

The leave trichomes of wild species of Solanum berthaultii, by releasing adhesive viscous substances, provide protection against numerous insect pests of potato (Castell et al., 2006), including Coleoptera Chrysomelidae family, as the Colorado potato beetle Leptinotarsa decemlineata (Coleoptera: Chrysomelidae) and D. speciosa (Lara et al., 2000).

Combining the resistance of wild potato species and agronomic traits of cultivated species is one of the efforts of the crop breeding programs. One of the main results is the cultivar "Prince Hairy" NYL 235-4, resistant to $L$. decemlineata, derived from crosses of wild potato ( $S$. berthaultii), which, besides containing good agronomic traits, loses three to seven times less productivity than genotypes susceptible to the insect. The high level of resistance of NYL 235-4, non-preference for feeding (antixenosis) type, has been associated with the presence of glandular trichomes on the foliage (Fisher et al., 2002).

In Brazil, NYL 235-4, a clone with resistance to the Colorado potato beetle, has been used as standard in studies of the resistance of potato to $D$. speciosa (Lara et al., 2000, 2004; Souza et al., 2005, 2006; Furiatti, 2009), including as a gene provider. In this context, clonal families C2337 and C2362, developed by the potato breeding program of Embrapa and containing NYL 235-4 genes, demonstrated foliar resistance to Diabrotica spp. (Souza et al., 2008). The cultivar Asterix has been used as a pattern of susceptibility to the insect (Salles, 2000).

Experiments on the resistance of potato to $D$. speciosa have been carried out in greenhouse, in tests with and without choice of plant by the insect. Initially, plants, in pots hidden by cages lined with screen, are infested with adult insects, for visual estimation of leaf area consumed (Lara et al., 2004), being subsequently evaluated the index of damage caused by larvae to tubers (Salles, 2000).

Based on available knowledge about the effects that plants of Solanum spp. can exert on different species of Chrysomelids, this research aimed to characterize the behavior of six advanced clones of the potato breeding program of Embrapa in relation to the resistance to $D$. speciosa, in conditions of artificial infestation at greenhouse.

\section{MATERIAL AND METHODS}

The experiment was conducted on April 4, 2012, in a greenhouse at Temperate Climate Center of Brazilian Agricultural Research Corporation, Rio Grande do Sul state, Brazil. Six genotypes were evaluated, four being advanced potato clones developed by Embrapa Potato Breeding Program, with $S$. berthaultii in their genealogies (C2337-06-02, C2337-18-02, C234201-02, C2362-02-02) and unknown reaction to the insect; one clone resistant to D. speciosa, cv. "Prince Hairy" NYL 235-4 (Furiatti, 2009) and one susceptible cultivar, Asterix (Salles, 2000).

Tubers were planted in polyethylene bags, with a capacity of $5 \mathrm{~L}$, containing Plantmax ${ }^{\circledR}$ peat substrate. The plants (one per pot), under temperature of 18 to $30^{\circ} \mathrm{C}$ were alternately irrigated every two days and treated, on June 8, 2012, with the fungicide mefenoxan (Metalaxyl-M) + mancozeb at doses of $250 \mathrm{~mL} / 100 \mathrm{~L}$, aiming to avoid the incidence of diseases such as late blight, caused by the fungus
Phytophthora infestans. In the previous plant infestation period, a luminous trap was turned on, daily, at sunset, in the greenhouse, to catch insect pests of natural occurrence.

During the stolon emission phase at 30 days after planting (DAP), the pots with the plants were arranged in factorial design (two plants/genotype) in six replications, and covered individually by a cylindrical cage $[1.2 \mathrm{~m}$ (height) $\mathrm{x}$ $0.6 \mathrm{~m}$ (diameter)] of wire and screened mesh fabric (tulle). The experimental plot consisted of two plants of each genotype. Right after the isolation in cages, the plants from one of the rows were infested by five $D$. speciosa couples; the couples were sexed according to White (1977), establishing a no-choice condition of the host plant. The plants from the other row (controls) remained uninfected in order to establish the rate of production decrease.

Adults of D. speciosa used in this research were obtained by the method of creation described by Ávila et al. (2000), however, with modifications. In the larval stage, the insect was raised on a natural diet consisting of maize seedlings, containing the expanded vermiculite as substrate (sterile) in plastic pots $(20 \mathrm{~cm}$ diameter x $10 \mathrm{~cm}$ height). For this purpose, a first layer of vermiculite ( $40 \mathrm{~g}$ ) was placed in the bottom of a plastic container and on this layer distilled water was used $(80 \mathrm{~mL})$. Then, 50 maize seeds were placed on the first layer of vermiculite and covered by one second layer of this material (50 g), and more $100 \mathrm{~mL}$ of distilled water was added, being the containers packed in heated room $\left(25 \pm 2^{\circ} \mathrm{C}\right.$; UR $60 \pm 10 \%$ ). After four days, when the seminal radicles have emerged, the seedlings were infested in the roots with 150 neonate larvae (3 larvae/seedling) using a thin bristle brush. After 10 days of growth, about 100 larvae were transferred, by sieving, from the infested container to plastic container containing vermiculite and 50 new maize seedlings (obtained by the process described above). The larvae were kept in this container up to reach their pupal stage.

Adults of D. speciosa that emerged, still in the larval rearing containers were packed in acrylic cage $(39 \mathrm{~cm}$ wide $\mathrm{x}$ 
$51 \mathrm{~cm}$ long x $51 \mathrm{~cm}$ high) containing a diet consisting of one plant of bean, cultivar Carioca (maintained in an Erlenmeyer flask with water), carrot slices ( $1 \mathrm{~cm}$ wide $\times 2 \mathrm{~cm}$ diameter) and honey solution $(10 \%)$ in cotton wool. The petioles of beans were fixed (with cotton) to the neck of the Erlenmeyer flask, whereas the sliced carrot and honey solution (cotton) were kept in Petri dishes.

A month after infestation, at the phenological stage of tuberization, injuries on the leaflets of potato caused by $D$. speciosa were visually estimated, attributing grades ( $\%$ of consumed area) in the lower, middle and top thirds of the plants. For this purpose, the method of Furiatti (2009) was adopted, based on the degree of defoliation using the following grading scale: $z e r o=$ no defoliation; $1=$ up to $5 \% ; 2=5$ to $10 \%$; $3=10$ to $15 \% ; 4=15$ to $20 \% ; 5=20$ to $30 \%$. In the experiment, however, two more defoliation grades were used: $6=$ 30 to $45 \%$ and $7=$ greater than $50 \%$.

At 70 DAP, at tuber growth stage, in order to keep the infestation of the potato genotype by $D$. speciosa, of the leaves of each plant, more three couples (adult) were released and in the roots, using a fine moistened brush, eight larvae until $3^{\text {rd }}$ instar. The experiment was completed on July 16, 2012 at 103 DAP (stage of tuber maturation and plant senescence), when the number of perforations, caused by the larvae, in all tubers harvested from each plant was recorded.

The evaluation of the agronomic traits was based on the methods describe by Souza et al. (2005), attributing grades to the appearance of tubers according to the following scale: $1=$ excellent appearance (attractive light or intense red-colored tubers, smooth skin, elongated and uniform shape, shallow eyes, medium to large size) and $5=$ very bad appearance (rough tubers, deep eyes, low productivity, irregular shape and other defects); In relation to tuber uniformity, the grades were $1=$ uniform (tubers with uniform sizes and shapes) up to $5=$ uneven (tubers with different sizes and shapes). The tubers were classified according to the transverse diameter, in order to evaluate its production. Those with more than $45 \mathrm{~mm}$ diameter were considered commercial, the number and the weight were recorded. The roughness of the tubers was evaluated in comparison to the witnesses, using the grades 1 (smooth) up to 5 (rough). For the eye-depth (vegetative bud), the grades were also from 1 (shallow eye) to 5 (deep eye).

The rate of the reduction of production ( $\% \mathrm{RP})$ of potato genotypes was calculated using the formula: RP\% $=[(\mathrm{S}-\mathrm{C}) / \mathrm{S}] \times 100$, where $\mathrm{S}$ and $\mathrm{C}$ are the weight of tubers in plots without and with infestation of adults and larvae of D. speciosa respectively.

The original data obtained, processed in $\sqrt{x+0,5}$ (grades attributed to the defoliation in the lower, middle and top thirds of the plants; number of holes in the tubers; average weight; total production; total number of tubers; appearance; uniformity; roughness of the skin and eye depth) or arc sen $\sqrt{x / 100}$ (reduction of production; $\%$ of marketable tubers) to standardize and reduce the heterogeneity of variations, were submitted to the analysis of variance using Genes, v. 7.0 software (Programa Genes, 2009), and the averages were compared by the Scott \& Knott test at 5\% significance.

\section{RESULTS AND DISCUSSION}

Under without choice condition of potato genotypes by adults of $D$. speciosa, at 30 days after the infestation, some significant differences were observed in relation to defoliation of the lower and middle thirds of the plants (Table 1). The genotypes differed, however, in relation to the attack on the top third of the plant. The resistant clone NYL 235-4 and the advanced clones C2342-01-02 and C2337-18-02 formed a less defoliated group, whereas the clones C2337-06-02 and C2362-02-02, together with cultivar Asterix, were the most defoliated group. In the general context of defoliation, in the three parts of the plants, a higher level of resistance behavior was observed in clones $\mathrm{C} 2342$ 01-02 and C2337-18-02, similarly to the resistant clone NYL 235-4.

The significant differences between potato genotypes in relation to defoliation by $D$. specios $a$ observed one month after the infestation only on the top third of the plants, where the attack was greater (Table 1), highlighting the clone NYL 235-4 (resistance pattern) among the least attacked ones, showed this part of the plant to be the most favorable for evaluation of insect resistance. This distinction of greater attack and, therefore, better differentiation about leaf consumption on the top third of the plants becomes important, considering that variation in the rate of damage due to the age and plant part attacked may occur (Cranshaw \& Radcliffe, 1980). Furthermore, as in preference for feeding test, without choice of the host plant, the insect can cause considerable damage even to genotypes with resistance characteristics (Lara, 1991), the low rate of defoliation of the clones C2342-01-02 and C2337-18-02 is even more evident.

Three groups of potato genotypes differed significantly in relation to drilling of tubers by larvae of $D$. speciosa (Table 1). The cultivar Asterix, the most attacked one, confirmed to be susceptible to the insect. The clone C2337-18-02 showed intermediate damage whereas the clones C2337-0602, C2342-01-02, C2362-02-02 and NYL 235-4 showed resistant behavior to the attack by larvae. The authors observed that the clone C2337-18-02, with the lowest level of defoliation, showed intermediate rate of drilling on tubers. This behavior can be related to the lack of relationship between the damage in leaves and tubers, caused by adults and larvae of $D$. speciosa, respectively (Furiatti, 2009). On the other hand, potato plants submitted to defoliation stresses, resulting from innumerous factors, increase in tubers, the content of glycoalkaloid solanine, which can be considered a natural insecticide for many insect species as L. decemlineata and Empoasca fabae (Hemiptera: Cicadellidae) (Hlywka et al., 1994) which may have interfered, at different levels, in the behavior of genotypes evaluated. Therefore, the behavior of the clone C2337-06-02, with higher and lower rates of defoliation and drilling of tubers by D. speciosa, respectively (Table 1), can be the result of an increase in alkaloid content. 
Table 1. Grades attributed to defoliation transformed into $\sqrt{\mathrm{x}+0,5}$, in lower (TI), medium (TM) and superior third of the plants (TS), at 59 days after emergence, caused by artificial infestation of adults and number of holes in tubers (NFT), at 103 days post planting caused by the larvae Diabrotica speciosa in six potato genotypes in greenhouse [notas atribuídas à desfolha transformadas em $\sqrt{x+0,5}$, nos terços inferior (TI), médio (TM) e superior (TS), aos 59 dias após a emergência, provocada por infestação artificial de adultos e número de orifícios nos tubérculos (NFT), aos 103 dias pós plantio, provocado pela larva-alfinete de Diabrotica speciosa, em seis genótipos de batata em casa-de-vegetação]. Capão do Leão, Embrapa Clima Temperado, 2012.

\begin{tabular}{lccccc}
\hline Genotype & TI & TM & TS & Average value & NFT \\
\hline NYL 235-4 & $1.8 \mathrm{a} \mathrm{A}^{1}$ & $1.8 \mathrm{a} \mathrm{A}$ & $2.2 \mathrm{~b} \mathrm{C}$ & $2.3 \mathrm{~b}$ & $12.0(\mathrm{n}: 6.5)^{2} \mathrm{c}$ \\
C2342-1-02 & $1.6 \mathrm{a} \mathrm{A}$ & $2.6 \mathrm{a} A$ & $3.2 \mathrm{~b} \mathrm{~B}$ & $2.9 \mathrm{~b}$ & $31.0(\mathrm{n}: 3.2) \mathrm{c}$ \\
C2337-18-02 & $2.5 \mathrm{a} \mathrm{A}$ & $2.7 \mathrm{a} \mathrm{A}$ & $3.4 \mathrm{~b} \mathrm{~B}$ & $3.3 \mathrm{~b}$ & $50.8(\mathrm{n}: 6.7) \mathrm{b}$ \\
C2337-06-02 & $2.4 \mathrm{a} \mathrm{A}$ & $2.7 \mathrm{a} \mathrm{A}$ & $4.1 \mathrm{a} \mathrm{A}$ & $3.7 \mathrm{a}$ & $18.0(\mathrm{n}: 3.5) \mathrm{c}$ \\
Asterix & $2.1 \mathrm{a} \mathrm{A}$ & $3.1 \mathrm{a} A$ & $4.3 \mathrm{a} \mathrm{A}$ & $4.2 \mathrm{a}$ & $81.8(\mathrm{n}: 5.0) \mathrm{a}$ \\
C2362-02-02 & $2.3 \mathrm{a} \mathrm{A}$ & $2.6 \mathrm{a} \mathrm{A}$ & $4.7 \mathrm{a} \mathrm{A}$ & $4.2 \mathrm{a}$ & $25.8(\mathrm{n}: 4.7) \mathrm{c}$ \\
\hline Means & 2.1 & 2.6 & 3.7 & 3.4 & 36.5 \\
CV $(\%)$ & 16.97 & 12.59 & 8.32 & 8.25 & 20.14 \\
\hline
\end{tabular}

${ }^{1}$ Means followed by the same letter, lowercase in columns and uppercase in rows, do not differ, Scott \& Knott test, $5 \% ;{ }^{2}$ averages of assessed tubers. Scale of zero = no defoliation; 1 $=$ up to $5 \% ; 2=5$ to $10 \% ; 3=10-15 \% ; 4=15-20 \% ; 5=20-30 \% ; 6=30-45 \%$ and $7=$ greater than $50 \%$ ( ${ }^{1}$ valores médios seguidos por letras minusculas, iguais na coluna e maiúsculas iguais na linha, não diferem, teste Scott \& Knott, 5\%; ${ }^{2}$ média de tubérculos avaliados. Escala de notas zero $=$ sem desfolha; $1=$ até $5 \% ; 2=5$ a $10 \% ; 3=10$ a $15 \% ; 4=15$ a $20 \% ; 5=20$ a $30 \% ; 6=30$ a $45 \%$ e $7=$ superior a $50 \%$ ).

Despite the possibility of the defense mechanisms against $D$. speciosa in leaves and tubers of the potato plants being independent (Souza et al., 2006), identifying genotypes as NYL $235-4$ and C2342-1-02, which expresses resistant behavior in both parts of the plants, is advantageous (Table 1).

For the evaluation of agronomic traits of potato genotypes, with and without infestation of larvae and adults of D. speciosa (Table 2), significant differences between the average weights of tubers of the plants submitted to the insect attack were not observed. On the contrary, in the condition of uninfected plants, the clones C2362-02-02, C234201-02 and NYL 235-4 stood out, forming a group with heavier tubers. The cultivar "Asterix" and the clones C2337-06-02 and C2337-18-02 formed another group with tubers with lower average weight.

Under infestation of larvae and adults of $D$. speciosa, the clones NYL 235-4 and C2337-18-02 reached highest total weight of tubers, producing an average of 6.5 more tubers/plant than the other genotypes, whose production did not differ (Table 2). This result is in accordance with the finding that the
NYL-235-4 showed tolerance to $D$. speciosa attack, showing the lowest rate of reduction in tubers production, differing from the other genotypes which formed another group with higher losses (Table 2). Thus, the clones C2341-01-02 and C2337-1802 that expressed non-preference for feeding as a resistance, when evaluated under aspect of tolerance to the insect attack, showed susceptibility behavior. This may have resulted from a likely preference for oviposition in certain genotypes associated with many factors of plants, as described by Lara (1991). Moreover, the potato plants have high sprouting ability, allowing to tolerate drastic defoliation levels, avoiding significant reductions in the production of tubers (Furiatti, 2009).

For the number of tubers produced per plant (NTT) (Table 2), no genotype difference in relation to the insect attack was observed. However, under the condition of plants without infestation by larvae and adults of $D$. speciosa, the genotype C2337-18-02 stood out with an average of 8.0 tubers, differing from the rest, which formed another group.

In the evaluation of commercial tuber production, no difference between the advanced clones and the commercial witnesses Asterix and NYL- 235-4, under artificial infestation of larvae and adults of $D$. speciosa, was noticed. However, for the condition of plants without insect infestation, the clone C2342-1-02 did not show any difference comparing to the resistant witness NYL 235-4, with production of $100 \%$ of commercial tubers. The other clones formed one group together with the cultivar (susceptible witness). These observations reinforce the predominance of resistant parents of the wild species $S$. berthaultii for these yield component traits, total number of tubers produced per plant and commercial classification, observed by Souza et al. (2008), since in potato breeding it is necessary to direct those combinations wherein the resistance in significant level is transmitted to most progenies providing maintenance and rising agronomic quality standards of the material on which is being working (Darmo \& Peloquin, 1991). 
Table 2. Potato genotypes evaluated with and without infestation (CI and SI) of Diabrotica speciosa under greenhouse and means of treatments for the variables weight (PM) $(\mathrm{g})$, total production $(\mathrm{PT})(\mathrm{g})$, reduction of production (RP) $(\%)$, total number of tubers $(\mathrm{NTT})$ and $\%$ of marketable tubers (\%TC) \{genótipos de batata avaliados com e sem infestação (CI e SI) de Diabrotica speciosa em casa-de-vegetação e média dos tratamentos para as variáveis: peso médio $(\mathrm{PM})(\mathrm{g})$, produção total $(\mathrm{PT})(\mathrm{g})$, redução de produção $(\mathrm{RP})(\%), \mathrm{n}^{\circ}$ tubérculos totais (NTT) e \% tubérculos comerciais (\%TC)\}. Capão-do-Leão, Embrapa Clima Temperado, 2012.

\begin{tabular}{|c|c|c|c|c|c|c|c|c|c|}
\hline \multirow{2}{*}{ Genotype } & \multicolumn{2}{|c|}{ PM (g) } & \multicolumn{2}{|c|}{ PT (g) } & \multirow{2}{*}{$\begin{array}{l}\text { RP } \\
(\%)\end{array}$} & \multicolumn{2}{|c|}{ NTT } & \multicolumn{2}{|c|}{ TC (\%) } \\
\hline & CI & SI & CI & SI & & CI & SI & CI & SI \\
\hline Asterix & $13.6 \mathrm{a} \mathrm{A}^{1}$ & $14.5 \mathrm{~b} \mathrm{~A}$ & $62.1(\mathrm{n}: 30)^{2} \mathrm{~b} \mathrm{~A}$ & $78.2(\mathrm{n}: 33)$ b A & $20.6 \mathrm{a}$ & $5.0 \mathrm{a} \mathrm{A}$ & $5.7 \mathrm{~b} \mathrm{~A}$ & $82.8 \mathrm{a} \mathrm{A}$ & $87.8 \mathrm{~b} \mathrm{~A}$ \\
\hline C2337-06-02 & 29.9 a A & $18.3 \mathrm{~b} \mathrm{~A}$ & 83.7 (n:21) b A & 86.5 (n:30) b A & $3.2 \mathrm{~b}$ & $3.5 \mathrm{a} \mathrm{A}$ & $4.8 \mathrm{~b} \mathrm{~A}$ & $92.5 \mathrm{a} \mathrm{A}$ & $88.5 \mathrm{~b} \mathrm{~A}$ \\
\hline C2362-02-02 & $18.2 \mathrm{a} \mathrm{A}$ & $21.8 \mathrm{a} \mathrm{A}$ & $76.8(\mathrm{n}: 28) \mathrm{b} A$ & 101.8(n:31) b A & $24.6 \mathrm{a}$ & 4.7 a A & $4.6 \mathrm{~b} \mathrm{~A}$ & $94.4 \mathrm{a} \mathrm{A}$ & $93.3 \mathrm{~b} \mathrm{~A}$ \\
\hline C2342-1-02 & $31.8 \mathrm{a} \mathrm{A}$ & $29.1 \mathrm{a} \mathrm{A}$ & $95.2(\mathrm{n}: 19)$ b A & 108.2(n:24) b A & $12.0 \mathrm{a}$ & $3.2 \mathrm{a} \mathrm{A}$ & $4.7 \mathrm{~b} \mathrm{~A}$ & $95.8 \mathrm{a} \mathrm{A}$ & 100.0 a A \\
\hline NYL 235-4 & $29.3 \mathrm{a} \mathrm{A}$ & $22.4 \mathrm{a} \mathrm{A}$ & 124.2 (n:39) a A & 132.1(n:36) a A & $6.0 \mathrm{~b}$ & $6.5 \mathrm{a} \mathrm{A}$ & $6.0 \mathrm{~b} \mathrm{~A}$ & $84.2 \mathrm{a} \mathrm{A}$ & $100.0 \mathrm{a} \mathrm{A}$ \\
\hline C2337-18-02 & $19.5 \mathrm{a} \mathrm{A}$ & $18.8 \mathrm{~b} \mathrm{~A}$ & $127.5(\mathrm{n}: 40)$ a A & $150.1(\mathrm{n}: 48)$ a A & $15.1 \mathrm{a}$ & 6.7 a A & $8.0 \mathrm{a} \mathrm{A}$ & $91.5 \mathrm{a} \mathrm{A}$ & $87.5 \mathrm{~b} \mathrm{~A}$ \\
\hline Means & 23.7 & 20.8 & 94.9 & 109.5 & 13.6 & 4.9 & 5.6 & 90.2 & 92.8 \\
\hline CV (\%) & 30.41 & 29.29 & 14.41 & 24.52 & 18.05 & 19.91 & 24.09 & 20.02 & 11.34 \\
\hline
\end{tabular}

${ }^{1}$ Means followed by same letters, lowercase in columns, and uppercase on lines, do not differ, Scott \& Knott, 5\%; ${ }^{2}$ average values of evaluated tubers ( ${ }^{1}$ médias seguidas da mesma letra, minúscula na coluna, e maiúscula na linha, não diferem, Scott \& Knott, 5\%; ${ }^{2}$ média de tubérculos avaliados).

Regarding the characteristics of tubers, the cultivar Asterix and the clone C2337-06-02 showed intermediate appearance of the tubers $(\operatorname{grade}=3)$, differing from the other genotypes, whose appearance was very bad (grade= 5), including clone NYL-235-4, highly resistant to the attack of rootworm (Table 3). In the condition of plants without infestation by larvae and adults of $D$. speciosa, the genotypes Asterix, NYL 235-4, C2337-06-02 and C2337-18-02 showed excellent appearance of tubers, comparing to clones C2342-1-02 and C2362-02-
02, with lower appearance. Although the overall appearance is a subjective character, whose evaluation depends on the experience of the breeder, in the fall, the degree of appearance decreases as climate conditions becomes adverse to the normal development of potato plants (Andreu, 2005).

No differences between the genotypes, in relation to the uniformity of the tubers produced by plants submitted to infestation of larvae and adults of $D$. speciosa were observed. However, under the condition of plants without infestation, the clones C2337-
06-02, C2337-18-02 and C2362-02-02 formed tubers with more elongated size and shape, differing from the other genotypes, which showed rounded shape, including witness cultivars Asterix and NYL 235-4.

Under the condition of plants infested by $D$. speciosa, six genotypes were graded $(4.3 \leq \mathrm{AP} \leq 5.0)$ for greater roughness of the tuber skin (Table $3)$. The same result was noticed in relation to most of the genotypes, in the condition of plants without infestation, except clone C2337-06-02, which showed smoother tubers $($ grade $=1.7$ ).

Table 3. Appearance (A), uniformity (U), skin roughness (AP) and depth of eyes (PO) of potato genotypes with and without infestation (CI and SI) of Diabrotica speciosa under greenhouse [aparência (A), uniformidade (U), aspereza da película (AP) e profundidade de olho (PO) de genótipos de batata com e sem infestação (CI e SI) de Diabrotica speciosa em casa-de-vegetação]. Capão-do-Leão, Embrapa Clima Temperado, 2012.

\begin{tabular}{|c|c|c|c|c|c|c|c|c|}
\hline \multirow{2}{*}{ Genotype } & \multicolumn{2}{|c|}{$\mathbf{A}$} & \multicolumn{2}{|c|}{$\mathbf{U}$} & \multicolumn{2}{|c|}{ AP } & \multicolumn{2}{|c|}{ PO } \\
\hline & CI & SI & CI & SI & CI & SI & CI & SI \\
\hline Asterix & $3.0 \mathrm{~b} \mathrm{~A}^{1}$ & $2.3 \mathrm{~b} \mathrm{~A}$ & $3.0 \mathrm{a} \mathrm{A}$ & $3.0 \mathrm{a} \mathrm{A}$ & $5.0 \mathrm{a} \mathrm{A}$ & $5.0 \mathrm{a} \mathrm{A}$ & $4.3 \mathrm{a} \mathrm{A}$ & $3.0 \mathrm{a} \mathrm{A}$ \\
\hline NYL235-4 & 5.0 a A & $1.0 \mathrm{~b} \mathrm{~A}$ & $5.0 \mathrm{a} \mathrm{A}$ & $3.7 \mathrm{a} \mathrm{A}$ & $5.0 \mathrm{a} \mathrm{A}$ & $5.0 \mathrm{a} \mathrm{A}$ & $5.0 \mathrm{a} \mathrm{A}$ & $1.0 \mathrm{~b} \mathrm{~A}$ \\
\hline C2337-06-02 & $2.3 \mathrm{~b} \mathrm{~A}$ & $1.7 \mathrm{~b} \mathrm{~A}$ & $2.3 \mathrm{a} \mathrm{A}$ & $1.7 \mathrm{~b} \mathrm{~A}$ & $4.3 \mathrm{a} \mathrm{A}$ & $1.7 \mathrm{~b} \mathrm{~A}$ & $2.3 \mathrm{a} \mathrm{A}$ & $2.3 \mathrm{a} \mathrm{A}$ \\
\hline C2337-18-02 & $5.0 \mathrm{a} \mathrm{A}$ & $1.0 \mathrm{~b} \mathrm{~A}$ & 4.3 a A & $1.0 \mathrm{~b} \mathrm{~A}$ & $5.0 \mathrm{a} \mathrm{A}$ & $5.0 \mathrm{a} \mathrm{A}$ & $3.7 \mathrm{a} \mathrm{A}$ & $1.0 \mathrm{~b} \mathrm{~A}$ \\
\hline C2342-1-02 & $5.0 \mathrm{a} \mathrm{A}$ & $4.3 \mathrm{a} \mathrm{A}$ & 4.3 a A & 4.3 a A & $5.0 \mathrm{a} \mathrm{A}$ & 4.3 a A & 4.3 a A & $2.3 \mathrm{a} \mathrm{A}$ \\
\hline C2362-02-02 & 5.0 a A & $5.0 \mathrm{a} \mathrm{A}$ & $3.0 \mathrm{a} \mathrm{A}$ & $2.3 \mathrm{~b} \mathrm{~A}$ & $5.0 \mathrm{a} \mathrm{A}$ & $5.0 \mathrm{a} \mathrm{A}$ & $1.7 \mathrm{~b} \mathrm{~A}$ & $1.0 \mathrm{~b} \mathrm{~A}$ \\
\hline Means & 4.2 & 2.6 & 3.7 & 2.7 & 4.9 & 4.3 & 3.5 & 1.8 \\
\hline CV (\%) & 16.19 & 22.49 & 23.66 & 27.31 & 8.07 & 11.99 & 25.02 & 29.85 \\
\hline
\end{tabular}

${ }^{1}$ Means followed by same letters, lowercase on the column, and uppercase on the line, do not differ, Scott \& Knott, 5\%; A= tuber appearance $(1=$ very good to $5=$ poor $)$ $\mathrm{U}=$ uniformity of tubers $(1=$ uniform to $5=$ disuniform $)$; $\mathrm{AP}=$ skin roughness $(1=\mathrm{smooth}$ to $5=$ rough $)$;O= depth of the eyes $(1=$ shallow to $5=$ deep $)\left\{{ }^{1}\right.$ médias seguidas da mesma letra, minúscula na coluna e maiúscula na linha, não diferem, Scott \& Knott, 5\%; $\mathrm{A}=$ aparência de tubérculo (1= ótima a 5= péssima); $\mathrm{U}=$ uniformidade de tubérculo $(1=$ uniforme a $5=$ desuniforme); $\mathrm{AP}=$ aspereza de película $(1=$ lisa a $5=$ áspera $) ; \mathrm{PO}=$ profundidade do olho $(1=$ raso a $5=$ profundo $)\}$. 
The roughness of the tubers has great influence on commercial acceptance of in natura product by consumers, who prefer the smooth and shiny plants (Souza et al., 2008). The texture of the skin, despite being a high heritability trait, is highly affected by environmental changes such as humidity, soil type and disease (Andreu, 2005), which could be related to the results obtained in this work.

In relation to eye-depth (vegetative bud), in the tubers, the clone C2362-0202 stood out from the others, showing shallower structures, in the condition of plants infested by larvae and adults of $D$. speciosa (Table 3). Under the condition of plants without infestation, the clones NYL 235-4, C2337-18-02 and C236202-02 formed one group with lower value for eye depth, differing from the other genotypes. Some studies infer the possibility of selecting, in the SouthBrazilian conditions, clones of potato introduced with high levels of resistance to attack by insect pests and acceptable agronomic traits (Souza et al., 2006) on the contrary, that resistant clones from crosses between $S$. tuberosum and wild species can add numerous genetic traits that are undesirable from the agronomic point of view, such as tubers with very deep eyes (Kalazich \& Plaisted, 1991). Thus, in the potato breeding program process, some strategies should be adopted to give greater efficiency in the selection of genotypes, in any growing season, searching for desirable agronomic traits, such as the shallowest depth of vegetative buds ('eyes').

A further analysis of the results of this work shows that the methodology used in artificial infestation of plants and tubers of potato, in greenhouse conditions, with larvae and adults of D. speciosa, without choice of host genotype (advanced clones and cultivars), serves to characterize the degree of resistance to insect attack. More specifically, the authors highlight the following results: 1) confirmation of the susceptibility of the cultivar Asterix and the resistance of clones C2342-0102 and NYL 235-4, both in the shoots and tubers; 2) response for the resistance of the clones C2337-06-02, C2342-
01-02, C2362-02-02 in relation to the drilling of tubers by larvae; 3 ) evidence that the clones NYL 235-4 and C233706-02 tolerate attack of D. speciosa larvae, based on a smaller loss of tuber production. Additionally, among the evaluated potato genotypes, derived from the wild species $S$. berthaultii under infestation of $D$. speciosa, some showed to add one or more determinant agronomic traits of greater commercial tubers acceptance, as elongated shape, smooth skin and shallower eyes.

\section{ACKNOWLEDGEMENTS}

The authors thank to CAPES, for the scholarship, and Embrapa Temperate Climate for providing seeds and structure for conducting the tests.

\section{REFERENCES}

ANDREU MA. 2005. Associação entre características agronômicas da batata nos plantios de primavera e outono no Rio Grande do Sul. Ciência e Agrotecnologia 29: 925-929.

ÁVILA CJ; TABAI ACT; PARRA JRP. 2000. Comparação de técnicas para criação de Diabrotica speciosa (Coleoptera: Chrysomelidae) em dietas natural e artificial. Anais da Sociedade Entomológica do Brasil 29: 257-267.

BOULOMYTIS VTG; JÚNIOR RB. 2013. Problemática no uso da terra e no manejo agrícola da bataticultura em Bueno Brandão, MG. Sociedade e Natureza 25: 303-316.

CASTEEL CL; RANGER CM; BACKUS EA; ELLERSIECK MR; JOHNSON DW. 2006. Influence of plant ontogeny and abiotic factors on resistance of glandular-haired alfalfa to potato leafhopper (Hemiptera: Cicadellidae). Journal of Economic Entomology 99: 537-543.

CIP- Centro Internacional de La Papa. 2010. Agricultural research for development. Facts and figures about potato. Disponível em < http://cipotato.org/potato/publications/ pdf/005449.pdf $>$ Acessado em fevereiro de 2013.

CRANSHAW WS; RADCLIFFE EB. 1980. Effect of defoliation on yield of potatoes. Journal of Economic Entomology 73: 131-4.

DARMO E; PELOQUIN SJ. 1991. Use of 2x tuberosum haploid-wild species hybrids to improve yield and quality in $4 \mathrm{x}$ cultivated potato. Euphytica, 53: 1-9.

FERNANDES MES; FERNANDES FL; SILVA DJH; PICANÇO MC; JHAMIC GN; CARNEIRO PC; QUEIROZ RB. 2012. Trichomes and hydrocarbons associated with the tomato plant antixenosis to the leafminer. Anais da Academia Brasileira de Ciências
84: 201-210.

FISHER DG; DEAHL KL; RAINFORTH MV. 2002. Horizontal resistance in Solanum tuberosum to Colorado potato beetle (Leptinotarsa decemlineata). American Journal of Potato Research 79: 281-293.

FURIATTI RS. 2009. Efeito de genótipos de batata sobre Diabrotica speciosa (Coleoptera: Chrysomelidae) em condições de campo. Revista Acadêmica: Ciências Agrárias e Ambientais 7: 101-107.

HLYWKAJJ; STHEPHENSON GR; SEARS MK; YADA RY. 1994. Effects of insect damage on glycoalkaloid content in potatoes (Solanum tuberosum). Journal of Agricultural and Food Chemistry 42: 2545-2550.

KALAZICH JC; PLAISTED RL. 1991. Association between trichome characters and agronomic traits in Solanum tuberosum $\mathrm{x}$ Solanum berthaultii hybrids. American Potato Journal 68: 833-847.

LARA FM. 1991. Princípios de resistência de plantas a insetos. São Paulo: Ícone Editora. $336 \mathrm{p}$.

LARA FM; POLETTI M; BARBOSA JC. 2000. Resistência de genótipos de batata (Solanum spp.) a Diabrotica speciosa (Coleoptera, Chrysomelidae). Ciência Rural 30: 927-931.

LARA FM; SCARANELLO AL; BALDIN ELL; BOIÇA JÚNIOR AL; LOURENÇÃO AL. 2004. Resistência de genótipos de batata a larvas e adultos de Diabrotica speciosa. Horticultura Brasileira 22: 761-765.

NUNES MUC. 2002. Produtividade e principais problemas fitossanitários de cultivares de batata em Sergipe. Horticultura Brasileira 20: 424-427.

PROGRAMA GENES. 2009. Aplicativo computacional em genética e estatística v.7.0. www.ufv.br/dbg/genes/genes.htm 2010 , acessado em outubro de 2012.

QUADROS DA; IUNG MC; FERREIRA SMR; FREITAS RJS. 2009. Composição química de tubérculos de batata para processamento, cultivados sob diferentes doses e fontes de potássio. Ciência e Tecnologia de Alimentos 29: 316-323.

SALLES LAB. 2000. Incidência de danos de Diabrotica speciosa em cultivares e linhagens de batata. Ciência Rural 30: 205-209.

SOUZA VQ; PEREIRAAS; FRITCHE NETO R; SILVA GO; OLIVEIRA AC. 2005. Potential of selection among and within potato clonal families. Crop Breeding and Applied Biotechnology 5: 199-206.

SOUZA VQ; PEREIRA AS; SILVA GO; CARVALHO FIF. 2006. Correlation between insect resistance and horticultural traits in potatoes. Crop Breeding and Applied Biotechnology 6: 278-284.

SOUZA VQ; PEREIRA AS; SILVA GO; CARVALHO FFI; OLIVEIRA AC. 2008. Insect resistance and horticultural trait genetic values of potato families. Journal of Crop Science and Biotechnology 11: 69-73.

WHITE R. 1977. Sexual characters of species of Diabrotica (Chrysomelidae: Coleoptera). Annals Entomological Society American 70: 168. 